Ingvill Rasmussen

Institutt for pedagogikk, Universitetet i Oslo

Andreas Lund

Institutt for lcererutdanning og skoleforskning, Universitetet i Oslo

\title{
Læringsressurser og lærerrollen - et partnerskap i endring?
}

\section{Sammendrag}

I artikkelen blir relasjonen mellom lceringsressurser og larerrollen undersøkt. Dataene som analyseres består av intervjuer av larere og elever $i$ fagene historie og engelsk på ungdomstrinnet og i videregående. Analysene viser sentrale temaer i lcerere og elevers erfaringer med lcreboka og Internett. Vi bruker kontinuumet fra lukkede til åpne ressurser som et begrepsmessig bakteppe for å speile det empiriske materialet. Ved å bruke lcerernes og elevenes egne utsagn har vi i analysene forsøkt å beskrive hva som karakteriserer undervisningspraksiser i dag. Våre analyser viser framveksten av det vi har kalt hybride praksiser. Dette er praksiser hvor lareboka har mistet sin suverene posisjon som eneste kunnskapskilde, noe som impliser at larere stilles overfor nye krav til både å bistå elevene i å vurdere troverdigheten i de Internettbaserte ressursene, og til å organisere undervisningen i forhold til trusselen fra ikkefaglige aktiviteter. Vi finner at lererne responderer ulikt på denne utviklingen, men en tendens ser ut til å vcre at de utvikler og tilpasser oppgaver og aktiviteter for sin elevgruppe - lcerere blir da i økende grad også designere av undervisningsopplegg.

Nøkkelord: lcerer, multiple ressurser, lcerebok, Internett

\begin{abstract}
The article investigates the relationship between learning resources and the teacher's role. The data analyzed consists of interviews with teachers and students in the school subjects of history and English at the secondary and at the upper secondary level. Our analysis shows the central themes that teachers and students communicated with regard to their experiences with the use of textbooks and the Internet. We use the continuum from closed to open resources as a conceptual backdrop to mirror the empirical material. Through the use of the teachers' and the students' statements we describe what characterizes teaching practices today. Our analyses show the emergence of what we have called hybrid practices. These are practices in which the textbook has lost its position as the ultimate source of knowledge. The implication is that teachers are faced with new requirements both to assist students in assessing the
\end{abstract}


credibility of the Internet-based resources, and to organize teaching in relation to the threat posed by activities that involve resources that may not be authoritative. We find that teachers respond differently to this trend, but a tendency seems to be that they develop tasks and activities tailor-made for their students, and increasingly become designers of educational activities.

Key words: teacher, multiple resources, textbook, Internet

\section{Innledning}

Læreboka har historisk sett vært sentral i utviklingen av lærings- og undervisningspraksiser i skolen (Bachmann, 2005; Skjelbred \& Åmotsbakken, 2008). Studier har vist at lærere ofte planlegger undervisningen med utgangspunkt i læreboka, og at kombinasjonen lærer, lærebok, prøver og vurdering utgjør en tett kobling. Ikke bare i Norge, men i klasserom verden over (Alexander, 2000; Haug, 2011). Læreboka har formidlet det innholdet som skal læres og har fungert som en slags "partner" i klasserommets samtaler: "the school texts and reference books that provide the documentary base for schooling have become, in a sense, the text that talks" (Horowitz \& Olson, 2007: 55). Da grunnskolen ble innført i 1739 var trolig Fadervår elevenes første møte med en tekst, og læreren var prest (Skjelbred, 2010). Denne religiøse teksten "talte" til elevene som udiskutabel autoritet. Imidlertid endret dette forholdet seg når opplysningstekster som formidlet praktiske ferdigheter og skolefag kom inn i skolen. Andre sentrale endringer i læremiddelfeltet er Godkjenningsordningen for lærebøker som ble innført i 1889, og senere avviklet i 2000. Men tross denne formelle endringen så kan dagens lærebøker, også uten "godkjenningsstempelet”, fortsatt betraktes som en autoritet som regulerer og sikrer "pensum" i undervisningen i forhold til mål fastsatt i statlige læreplaner (Bachmann, 2005). Dette gjelder også i andre land, the American Textbook Council har karakterisert lærebokas rolle i undervisningen som "de facto curriculum” (den egentlige læreplanen) (Council, 1994). Likevel er det i Norge svært begrenset med forskning på bruk av lærebøker, det vanligste er begrenset til innholdsanalyser av enkeltverk (Juuhl, Hontvedt, \& Skjelbred, 2010).

Samtidig er læring og undervisning slik den tradisjonelt har vært organisert og praktisert i skolen, i endring. En endring som i stor grad kommer som en følge av den økte bruken av nettbaserte og digitale teknologier, kommunikasjonsformer og nye kompetansekrav som i økende grad krever kildekritikk, utvelgelse og bruk av relevante ressurser i ulike oppgaver (Säljö, 2010). Gjennom teknologier som opphever begrensninger i tid og rom ser vi i dag en tendens til å gå fra et regulert og "lukket læringsunivers” til et stadig mer “åpent læringsunivers“ der det historisk stabile forholdet mellom lærebok, oppgaver, prøver og vurdering utfordres av digitale teknologier, kommunikasjonsformer 
og en ny kommunikasjonsøkologi. I dette nye landskapet integreres ulike typer teknologier og medier mot mer sammenvevde informasjons- og kommunikasjonstjenester, en utvikling som ofte kalles konvergens. Datamaskiner og digitale ressurser er derfor å betrakte som svært mangfoldige og forstås og anvendes ulikt av lærere og elever. Dette er ressurser som "taler” på nye måter og som åpner opp for en rekke nye muligheter for undervisning og læring i forhold til en lærebok. Teknologiene er også i økende grad allestedsnærværende. Det betyr at vi må forholde oss til dem også på steder der vi ikke ønsker at de skal ha like stor plass - elever må til tider minnes om å slå av mobilen eller legge vekk PCen for å høre etter hva læreren sier. Imidlertid har samspillet mellom tradisjonelle lærebøker og digitale læringsressurser vist seg å primært bli ivaretatt av ildsjeler og enkeltlærere samt læremiddelprodusenter, det er vanskelig å få øye på klare didaktiske perspektiver på et slikt samspill (Juuhl, Hontvedt, \& Skjelbred, 2010). En slik situasjon setter lærere på nye prøver og krever en ny type bevissthet omkring hvordan vi anvender og forstår informasjonen vi møter og hvordan vi kommuniserer og anvender digitale verktøy. I denne artikkelen ønsker vi derfor å rette søkelyset mot konsekvensene de nye ressursene har for lærerens undervisning.

På samme måte som vi opererer med en skala mellom åpne og lukka læringsunivers, skiller vi også mellom åpne og lukka ressurser. Lukka ressurser er komprimerte og autoritative i den forstand at de fanger opp mål og kompetanser angitt i en læreplan. Fagdiskursen er lærebokas, og kan ligge langt fra elevens hverdagsspråk. Der de også tilbyr oppgaver inviterer disse gjerne til systematiske oppsummeringer. Åpne ressurser krever at elevene selv må ta større ansvar for utvalg og prioriteringer. Disse er ikke nødvendigvis formidlet gjennom en spesifikk fagdiskurs og er derfor i mindre grad preskriptive og hegemoniske. Samtidig er disse mer typiske for læringsressurser vi møter i vår livsverden, utenfor skolen (se også Blikstad-Balas, 2014, for en utvidet diskusjon). Skillene mellom åpne og lukka ressurser er selvsagt en overforenkling. Ressurser får sin betydning i bruk og slik sett kan en "lukka" ressurs i praksis være åpnende for en undersøkende og kreativ læringsprosess. Poenget med skillet er å innlede til en drøfting av hvilken funksjon ulike ressurser har i læringsprosesser - hvordan de “deltar” i elevene og lærernes interaksjoner. For å se nærmere på den nye læremiddelsituasjonen, vil vi analysere intervjuer som er gjort med både lærere og elever om deres bruk av læringsressurser. Datamaterialet er hentet fra forskningsprosjektene TWEAK og Ark\&App. ${ }^{1}$ I den empiriske analysen av intervjuene bruker vi et kontinuum fra lukkede til åpne læringsressurser, som et begrepsmessig bakteppe for å speile læreres og elevers opplevelser og erfaringer. I intervjuene snakker lærerne og elevene om bruk av ulike typer ressurser i undervisning. Intervjuene er foretatt etter undervisningsperioder hvor flere ulike typer analoge og digitale ressurser har vært brukt i fagene engelsk og historie. 


\section{Læringsressurser i skolefagene engelsk og historie}

Engelsk og historie er valgt som faglige linser, både fordi det er sentrale skolefag, men også fordi de er blant de fagene der digitale teknologier har hatt lengst og mest utbredt virketid (A. Lund, 2004). Vi mener derfor erfaringer fra disse fagene kan ha en viss overføringsverdi til andre fagområder. Engelskfaget har historisk sett $\mathrm{i}$ dag en helt sentral posisjon som verdens ledende kommunikasjonsspråk, og denne endringen er nært knyttet til globalisering og digitale nettverksteknologier. Engelsk - både som verdensspråk, vitenskapsfag, og følgelig som skolefag - er i endring. Faget speiler ikke lenger bare kulturer og språknormer der engelsk er førstespråk, men en interkulturell kontekst der engelsk er et globalt språk, sterkt understøttet av språkets unike posisjon som det mest utbredte og brukte språket på Internett (Brutt-Griffler, 2004; Crystal, 2001). Dette betyr at læringsressurser kan komme til å spille en noe annen rolle enn det vi er vant til fra den klassiske læreboka med tekster og oppgaver som har en sterk tilknytning til læreplanene; nå bidrar de også til å utvikle "Global Citizenship” og interkulturell kompetanse (Gimenez \& Sheehan, 2008). Vi vet at norske elever har gode resultater i engelsk, iallfall så lenge nivået ikke er for avansert eller spesialisert, og at de også i et europeisk perspektiv scorer relativt høyt (Bonnet, 2004). Imidlertid viser nyere undersøkelser at det inntrer en form for stillstand i utviklingen rundt Vg1, og at programfagene i engelsk ikke virker befordrende på den videre faglige utviklingen i den grad man kunne ønske. Norske elever ser ut til å beherske godt engelsk på et hverdagsnivå, mens de strever med mer spesialiserte diskurser (Hellekjær, 2009, 2012). Dette er selvsagt forhold som impliserer langt mer enn bruken av læringsressurser, men det er rimelig å anta at også slike forhold vil være interessante å se i lys av hvordan økende tilgang til digitale og nettverksbaserte læringsressurser medierer, eller kanskje begrenser, progresjon i elevenes faglige utvikling.

I historiefaget er strategisk kildegransking tett knyttet til fagkompetansen (Lund, 2009, 2011; Wineburg, 2001). Internett og økt digitalisering har gjort at mangfoldet i kilder i dag er enormt. Når disse ressursene tas i bruk møter elevene ofte informasjon som er fragmentert og til og med motstridende, med de utfordringer det stiller til å skape mening og å syntetisere ulike informasjonskilder (Anmarkrud, Bråten, \& Strømsø, 2014; Säljö, 2010). Samtidig har studier vist at historieundervisningen svært ofte er knyttet til og styrt av læreboka og at et ensidig fokus på innholdshistorie medfører at elevenes besvarelser ofte blir faktaorienterte (Furberg \& Rasmussen, 2012). Innholdshistorie og faktakunnskap er ikke tilstrekkelig for å forstå fortiden: du må også lære å tenke som en historiker - vite hvordan og hvorfor ( Lund, 2011; Wineburg, 2001). I en intervjustudie forteller historielærerne om nettopp denne utfordringen (Justvik, 2014). Lærerne forklarer lærebokas dominerende posisjon med at elevene trenger den, og sier at det er utfordrende å få nok tid til å arbeide med metode og kildegransking fordi selve stoffmengden $\mathrm{i}$ faget er så overveldende. Samtidig forteller lærerne at de ofte kombinerer boka med 
tilleggsstoff (Justvik, 2014). Utfordringen for historielæreren står overfor er altså blant annet å balansere undervisning i historiske epokers innhold og veiledning av elevers eget arbeid med primærkilder, slik at de også får erfaring og innsikt i hvordan historie blir til (Rasmussen, Gilje, Ferguson, Ingulfsen, \& Bakkene, 2014).

Gjennom analyse av intervjuer reises og besvares følgende spørsmål: Hvilke erfaringer har larere og elever fra praksiser der bruk av digitale ressurser inngår $i$ fagene engelsk og historie, og hvilke utfordringer og muligheter uttrykkes? Målet er å diskutere de ulike ressursenes funksjoner samt hvordan læreres og elevers praksiser lar seg influere av dem.

\section{Aktører og ressurser}

Forholdet mellom mennesker og kulturelle ressurser har blitt teoretisert fra flere perspektiver. Vi posisjonerer oss innenfor et sosiokulturelt perspektiv og tar som utgangspunkt at all aktivitet foregår med kulturelle ressurser eller artefakter både språklige og materielle. Men som bl.a. James Wertsch (1998) har vist, endrer ikke kulturelle ressurser bare aktivitetene de inngår i, men også menneskene som tar ressursene i bruk. Teknologiene bidrar til å endre våre forestillinger og de begreper vi bruker for å beskrive hva vi mener at læring er: vår forventning til hva mennesker skal mestre og hvilke ferdigheter som bør kultiveres. Menneskelig aktivitet med artefakter (for eksempel ulike former for tekster) er derfor den minste meningsfulle analyseenheten innen det sosiokulturelle perspektivet, fordi grunnantagelsen er at felles bruk og produksjon av materielle og språklige ressurser er grunnlaget for menneskelig meningsproduksjon. Dette er i tråd med den klassiske vygotskyanske tradisjonen der språket er først og fremst et handlingsmedium, det medierer praksiser og kognitiv utvikling i stedet for å reduseres til et representasjonsmedium (Vygotsky, 1986).

Shaffer og Clinton (2006) viser hvordan digitale teknologier endrer både kunnskapsproduksjon og kunnskapsrepresentasjon, det forfatterne omtaler som henholdsvis epistemologisk pluralisme og representasjonspluralisme. Dette kan forstås som en begrepsliggjøring av metaforen "det åpne universet”. Shaffer og Clinton (ibid.) diskuterer også angsten (blant lærere og andre) for hva som mistes i det åpne universet, panikken for at elever "ikke lærer det de skal" i forhold til læreplaner og praksiser som gir mennesket en helt avgjørende rolle i kunnskapskonstruksjonen.

\section{Metode: tematisk analyse av intervjudata}

Intervjuer består av fortellinger og beskrivelser fra intervjupersoner knyttet til temaer intervjueren er interessert i. Tema for forskningen er altså ikke intervjuet i seg selv, men temaene som diskuteres i intervjuene slik de fremtrer i møtet 
mellom samtalepartnerne (Kvale, 2010). Som nevnt innledningsvis er intervjudataene hentet fra to større forskningsprosjekter: TWEAK (2008-2012) og ARK\&APP (2012-2015). Førstnevnte prosjekt har hatt fokus på teknologibruk for elevsamarbeid, lærerinvolvering og kunnskapsdeling, og har sett spesielt på bruken av wikier i undervisningen. Prosjektet har gjennomført en rekke studier i fagene engelsk og historie på videregående skoler. ARK\&APPprosjektet undersøker hvilken betydning læremidlene har for undervisning og læring, prosjektet fokuserer på fagene engelsk og historie i tillegg til matematikk og naturfag. I alle studiene er det gjennomført intervjuer av lærere og elever. Forfatterne av denne artikkelen har vært med å utvikle intervjuguidene som er brukt i begge prosjektene. Intervjuene er gjennomført etter prosjektperiodenes slutt og fokuserer på erfaringer med og bruk av både digitale og analoge ressurser i læring og undervisning. Spørsmålene har således blitt tilpasset den aktuelle perioden og intervjuguiden har derfor ikke vært like styrende i alle intervjuene, selv om den fungerer strukturerende. $\mathrm{Vi}$ har benyttet gruppeintervjuer fordi samtaler mellom flere aktører ofte er en god måte å få data om variasjon i oppfatninger (Denzin \& Lincoln, 1998). Elevene er intervjuet i grupper på 4-5. Lærerne som jobbet i team er intervjuet sammen, mens de som ikke jobbet i team er intervjuet alene. lærerne er intervjuet Dataene som analyseres i denne artikkelen består av intervjuer av lærere og elever i fagene historie og engelsk på ungdom- og videregående trinn, og består av:

- 10 lærere, intervjuet en og en eller to sammen. Totalt 6 intervjuer.

- 59 elever, intervjuet i grupper. Totalt 15 intervjuer.

Intervjuene er foretatt på 6 ulike skoler i Østlandsområde, to ungdomsskoler og fire videregående skoler. I denne artikkelen vil vi bruke intervjudata for å hente ut aktørenes egne opplevelser av hvordan de forholder seg til læringsressurser. Et slikt emisk perspektiv (fortolket innenfra) bygger altså på persepsjonsdata (Denzin \& Lincoln, 1998). Formålet er altså ikke primært å få fram hva aktørene faktisk gjør (som er viktig nok), men hvordan de subjektivt fortolker sin bruk av læringsressurser. I analysen av materialet har vi brukt en tematisk tilnærming, men temaene som fremkommer i analysen er ikke nødvendigvis overlappende med intervjuguiden fordi både intervjueren og aktørene som intervjues vil utvikle, oppdage og tematisere nye forhold og sammenhenger i løpet av samtalen. Tematisk analyse er i følge Braun \& Clarke (2006, s. 77) den mest anvendte metoden i kvalitative studier, samtidig er dette en lite beskrevet og teoretisert tilnærming. Vi har gjennomført den tematiske analysen på følgende måte: Vi startet med å lytte og lese gjennom alle intervjuene for å skape fortrolighet til alt materiale, også de intervjuene vi selv ikke hadde foretatt. Underveis ble temaer i intervjuene markert og kodet med Nvivo, eller på papir og så ført inn i programmet. Etter hvert som vi jobbet med materialet, slo vi sammen og organiserte temaene hierarkisk. Denne delen av 
analysearbeidet innebærer en organisering av materiale med både horisontal og vertikal demarkasjon (skiller og sammenhenger) (Braun \& Clarke, 2006; King, 1998). Kvale og Birkmann (2009, s. 212) kaller denne prosessen for meningsfortetting. Førsteforfatteren har gjennomført det tematiske analyse-arbeidet, mens andreforfatteren har validert temaene. På den måten har vi sikret at fortolkningene av datakorpuset og anvendelsen av temaene er rimelig.

\section{Analyse}

Spørsmålene i intervjuguiden var relativt åpne og interessant nok så medførte dette at aktørene snakket mest om bruk av PCer og Internett. Andre temaer ble ofte snakket om i relasjon til bruk av Internett og PCer. Likevel var det fire hovedtemaer som preget innholdet i samtalene: Internett som læringsressurs, læreboka som læringsressurs, hybride praksiser der ulike ressurser spiller sammen, og et trusselbilde i form av distraksjon. I samtalene er disse temaene tett forbundet, og som analysene viser så beskriver aktørene sin bruk av læringsressurser som hybride praksiser hvor ulike ressurser spiller sammen og hvor distraksjon er en felles utfordring. I tråd med forskningsspørsmålet har vi derfor i analysene lagt vekt på å presentere lærerne og elevenes beskrivelser av og erfaringer med disse nye hybride praksisene, og hvilke utfordringer og muligheter som uttrykkes.

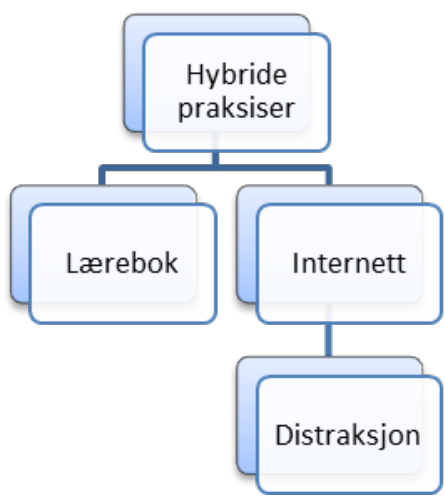

Figur1: Hovedtemaer i samtalene

Mens hovedtemaene var felles på tvers av lærer og elevintervjuene så var undertemaene og innholdet i samtalene forskjellig. Lærerne tematiserte for eksempel distraksjon ved å snakke om utfordringer knyttet til: "ansvar for egen lcring” og det ekstra arbeidet kontroll av elevenes PC bruk fører til for lærer. Elevenes derimot snakket om at det var lett å gjøre noe annet når det var "dødtid”, at de ikke alltid klarte å følge med eller skjønne det læreren snakket om og derfor "gikk på nettet”, og om pausene med litt spilling som ble for lange. Andre sentrale undertema som skilte lærernes utsagn fra elevenes var: differensiering og planlegging av undervisning og forholdet til læreplanen. Mens 
læremidlenes mulighet og begrensing i forhold til variasjon i undervisningen ble tematisert i både lærer og elevintervjuene, i tillegg til samarbeid og oppgavetyper. Noe overraskende så var det rent fagspesifikke relativt lite tematisert i disse intervjuene. Dette var spesielt overraskende i forhold til lærerintervjuene fordi dette er et vesentlig anliggende for læreres profesjonsfaglige digitale kompetanse (Lund, Furberg, Bakken, \& Engelien, 2014).

I analysene har vi derfor valgt å presentere lærerintervjuene og elevintervjuene hver for seg slik at de ulike undertemaene knyttes til henholdsvis lærere og elevers erfaringer og rolle. I det følgende lar vi en rekke utsagn fra elever og lærere fungere som empiriske bærere av de fire hovedtemaene og hvordan det vi har kalt hybride praksiser har vokst fram i krysningsflatene mellom det lukkede og det åpne universet. Temaene vi viser i utdragene finner vi i intervjuene med lærerne og elevene både fra perioden 2008-2012 og 2012-2015. Vi fant ikke noen store forskjeller mellom temaene i denne perioden. Derimot er de spesifikke applikasjonene som nevnes i intervjuene endret $\mathrm{i}$ denne perioden. Avslutningsvis gir vi en sammenfattende diskusjon hvor vi knytter temaene mot tidligere studier og kontinuumet fra lukkede til åpne læringsressurser. Slik sett har analysen en abduktiv karakter: mønstre og tematiske klynger belyses gjennom en teoretisk forståelse som blir mer generell og eksemplene får en videre forklaringskraft, ikke på populasjonsnivå, men på analytisk og teoretisk nivå (Denzin \& Lincoln, 1998).

\section{Intervjuer med lærere}

Vårt materiale viser altså en bevegelse mot det vi har kalt hybride praksiser i grenseflaten mellom de ulike læringsressursene. Tilgangen til Internett og PCer på videregående trinn ser ut til å være en primær driver for denne endringen. Internett ble i intervjuene ofte snakket om i relasjon til det enorme kildetilfanget. Flere av lærerne peker på at å bruke Internett som ressurs for læring er svært krevende for elevene. I det følgende utdraget fra et gruppeintervju med to historielærere fra videregående kommer dette tydelig frem:

\section{Utdrag 1.}

Lærer A: (...) som regel så søker de i Google, og så er det de to første tinga som popper opp, og det er det de bruker. Og hvis en av de står på engelsk, så velger man selvfølgelig den som er på norsk, så det er veldig sånn begrensa. Jeg ser at selv om de er gamle nok, sånn aldersmessig, så står de bom fast mange ganger i metode. De har ikke noen forutsetninger for å komme seg videre. Jeg har prøvd å variere og bruke litt mer IKT og litt varierte ting, men den største delen av elevmassen sier "åh, kan vi ikke bare bruke boka da”, de vender liksom tilbake til 
det litt trygge, “det står jo her”.

Lærer B: Ja, jeg er enig i det. Ja, det å søke etter kilder og vite hva du skal søke etter, det merker jeg, nettopp det at en del av de som sliter litt mer, de syns jo det er vanskelig, ikke sant, "hva skal jeg lete etter?”, "hva kan jeg trekke ut her?” (...). Det har jeg fått mange spørsmål om, "aktuell hendelse, liksom, hva betyr det? Hva er det liksom?” Ikke sant.

Lærerne mener at Internett skaper usikkerhet hos elvene. Det oppstår en spenning mellom læreboka, som er avgrenset og kjent for elevene, og det åpne og usikre som Internett representerer. I intervjuet påpeker lærerne at elevene har for lite kunnskap til å gjøre gode søk, de vet ikke hva de skal søke etter. Og når de finner en kilde, er det vanskelig for dem å trekke ut den kunnskapen de trenger for å løse oppgaven. Lærerne ser ut til å dele erfaringen med at svært mange elever opplever faglig bruk av Internett - som en ressurs for å finne, velge og tolke kilder, som for krevende. Dette er viktige argumenter for å beholde de mer autoriserte, lukkede og "trygge” læringsressursene, som i skolen er representert ved lcreboka.

At lareboka er en sentral læringsressurs ble klart utrykt av lærerne i intervjuene. Følgende utsagn er typisk: “Jeg tror nok at fortsatt så er det sånn $i$ norsk skole at bøker står veldig sterkt, og personlig så synes jeg ikke det er bare negativt”. Læreren gir her uttrykk for en personlig vurdering, hun mener det er bra at lærebøkene står sterkt i dagens skole. Og det var i denne sammenheng at læreboka ofte ble tematisert i relasjon til Internett og PCer, som vi også ser i de to første utdragene. I utdrag 1 . ble læreboka presentert som det trygge og avgrensede “det står jo her”. Læreboka blir således sett på som en motsetning til Internett, hvor elevene selv må finne ut hva de skal "lete etter" og hva de skal “trekke ut”. Slik sett står læreboka sterkt i møte med Internett fordi nettets åpne karakter gir elevene ekstra utfordringer. Men dagens lærebøker har også nettbaserte ressurser. I det følgende intervjuet med to engelsklærere på ungdomstrinnet tematiseres fordeler og utfordringer ved å bruke ikke bare læreboka, men også dens tilhørende websider.

\section{Utdrag 2.}

Lærer:

De fleste lærebøkene har jo også websider der man kan gå og klikke eller å gjøre interaktive øvelser- og det er veldig bra- og det at man kan variere undervisningen mer enn før. Da har man ekstra materiale [..] så kan de få en ekstra oppgave - men det har jo også sine utfordringer, det er jo klart

Intervjuer: Hva slags utfordringer er det? 
Lærer: $\quad$ Det er for eksempel kampen mot Facebook (Latter). Men det kan man jo styre ganske bra selv- siden man ikke driver med data så kan man bare be elevene stenge av [...], men det er klart at det er en distraherende faktor. Og det sier jo elevene selv.

Dette korte utdraget rommer alle de fire hovedtemaene. Læreren minner om at lærebøker i dag ikke kun er papirbasert, men også har "websider”. Situasjonen er altså ikke enten lcerebok eller Internett, men en hybrid som innebærer bruk av ressurser i kombinasjon. Fordelen som trekkes fram er muligheten for variasjon og differensiering, mens utfordringen er distraksjon- her representert ved Facebook. Utfordringen med bruken av lærebokas nettsider er altså ikke å finne, velge ut og vurdere informasjon, men det at elevene velger å gjøre noe annet når de har tilgang til Internett. Det er verd å merke seg at denne læreren mener at dette er noe en kan styre "ganske bra", men understreker at muligheten for å styre ikke tar bort utfordringen med distraksjon og at dette er noe elevene selv også uttrykker. Lærerne beskrev en unison erfaring med at elevene, selv på videregående trinn, har behov for å bli styrt og veiledet i sin bruk av Internett og PCer, men de skiller seg i synet på hvordan dette bør gjøres. Enkelte lærere uttrykte frustrasjon med hensyn til å styre voksne elever (jf. utdrag 1). Også andre studier viser at dette er en utfordring mange lærere opplever (BlikstadBalas, 2012). En av lærerne vi intervjuet uttrykte denne utfordringen som en følelse av å: "miste elevene", og at elevene har en tendens til " $a$ forsvinne inn $i$ sin separate verden". Dette sitatet uttrykker ikke bare en enkeltlærers hjertesukk, men også utfordringen digitale allestedsnærværende teknologier medfører. Nettbasert teknologi muliggjør deltagelse i parallelle aktiviteter og slik deltagelse har konsekvenser for hvor vi retter vår oppmerksomhet. I undervisning er det vesentlig å skape felles oppmerksomhet mot det som skal læres.

Et annet viktig undertema knyttet til de hybride praksisene var forholdet mellom læringsressurser og kompetansemål. I det følgende utdraget fra et intervju med en ungdomsskolelærer i samfunnsfag blir dette diskutert.

\section{Utdrag 3.}

Lærer:

..Men det er klart at i mange fag så er det en god hjelp. Du slipper å finne opp kruttet selv. Men, nei jeg har ikke tenkt tanken engang. Fordi- la oss nå si at vi har valgt feil lærebok, da. Da kan du følge den lojalt og ordentlig og du har fortsatt ikke gjort det du skulle.

Intervjuer: $\quad$ Fordi den ikke er god nok opp i mot kompetansemålene. [...]

Lærer: $\quad$ Da pleier jeg på min gammeldagse og kjedelige måte å gå 
igjennom det, da. Stort sett så har jeg veldig. Jeg spør elevene når jeg underviser, men stort sett så går jeg gjennom det, og så bruker jeg veldig mye tid på at de jobber med oppgaver

Læreboka representerer ingen garanti for at undervisningen har fulgt læreplanen lenger, ifølge denne læreren. Boka blir referert til som en kunnskapsressurs “ $d u$ slipper å finne opp kruttet selv”. Det er kompetansemålene, og ikke læreboka, som styrer denne lærerens utvalg av innhold og aktiviteter. Dette ser imidlertid ikke ut til å medføre at læreren legger opp til nye og mer innovative undervisningsformer. Tvert imot så beskriver læreren sin egen undervisning som en gjennomgang av stoff og arbeid med oppgaver - en "gammeldags og kjedelig måte”. Også andre nyere klasseromsstudier viser at lærere bruker svært mye tid på felles gjennomgang etterfulgt av individuelt oppgavearbeid (Klette et al., 2008; Rasmussen et al., 2014; Rasmussen, Rindal, \& Lund, 2014).

I vårt materiale ser det ut til at alderen og kvaliteten på læreboka også er en forklaring på fremveksten av hybride praksiser. At læreboka var "noen år gammel” og var "noe utdatert” ble av flere gitt som begrunnelse for å "supplere med tilleggsstoff fra nettet". En annen begrunnelse for å utforme eget tilleggsstoff - det vil si tekster, oppgaver og instruksjoner - var at oppgavene som var gitt i læreboka ikke passet elevpopulasjonen. Igjen trekkes muligheten for variasjon og differensiering fram som sentralt for lærernes bruk av flere typer læringsressurser. I to av lærerintervjuene i engelsk kom det fram at oppgavene i læreboka ble ansett som for enkle, mens andre lærere mente oppgavene og tekstene var for vanskelige. Det fagspesifikke i samspill med elevpopulasjonen, både på gruppe og individnivå, ser her ut til å spille en avgjørende rolle. Lærerne fortalte at de utviklet egne oppgaver med tekster og instruksjoner som de tilpasset sine elever. Dette ble ofte tematisert av lærerne når de snakket om sin undervisningsplanlegging. For eksempel så fortalte to lærere i engelsk at læreboka var mer sentral i deres planlegging tidligere. Nå brukte de læreboka kun som en av flere ressurser som de videreutviklet og justerte. Disse lærerne mente også at det var positivt for undervisningen med egenutviklede opplegg, og at aktivitetene i klasserommet ikke alltid burde være de samme som dem i boka. Når lærerne lagde egne opplegg følte "elevene seg mer sett av lcerer", mente de. Andre lærere fortalte om oppgaver eller aktiviteter som læreboka ikke inneholdt og som de derfor utviklet selv. Et eksempel på dette er mindre felles opplegg for hele klassen - eller "summeoppgaver" som enkelte lærere kaller det. Lærerne fortalte også at slike opplegg ofte blir beskrevet på ark som de deler ut og legger på Fronter eller Its learning.

Både tradisjonelle og nye læringsressurser ble ofte snakket om i sammenheng med nye kompetanser som lærerne mente samfunnet og/eller læreplanen krever. Samarbeid er et eksempel på en kompetanse som trekkes fram som spesielt viktig. Spesielt i intervjuene fra prosjektet TWEAK hvor 
elevene også brukte wikier var dette et tema. En av historielærerne gav her konkrete beskrivelser av hvordan han utviklet oppgaver og organiserte samarbeid, for eksempel ved at elevene måtte kommentere hverandres innlegg. Læreren mente at dette engasjerte og gav elevene en åpning for å problematisere fagstoffet. Andre lærere var derimot mer vage i sine beskrivelser av samarbeid. En av lærerne vi intervjuet uttrykte det på denne måten: "Jeg kaster dem mest ut $i$ det og så lcerer de underveis”. I vårt materiale ga lærerne få konkrete beskrivelser av hvordan de støttet elevenes samarbeidsprosesser når de snakket om viktigheten av å lære å samarbeide. Dette samsvarer med andre studier som viser at instruksjonene elevene mottar kan ha et noe implisitt og vagt artikulert uttrykk (Brevik, 2014), og at lærerprofesjonen har relativt svakere profesjonsspesifikt språk enn en del andre profesjoner (Jensen, 2008).

\section{Intervjuer med elever}

Intervjuene med elevene inneholdt de samme overordnede temaene som intervjuene med lærerne, men innholdet i samtalene var forskjellig. Elevene var mer opptatt av hvordan de rent praktisk skulle løse oppgavene de var satt til og de utfordringene de hybride praksisene stilte dem overfor. Denne praktiske tilnærmingen fikk også fram utfordringer ved faget, spesielt i historie. I historie representerer Internett et enormt kildetilfang og håndtering av mengde er en sentral utfordring for elevene. Som utsagnene viser, er ikke elevene uten erfaring. Elevene peker særlig på hvordan de utnytter raske oppslag og nærmest uendelig tilgang til informasjon på flere måter. Dette tematiseres imidlertid kun av elevene på videregående trinn i vårt materiale.

\section{Utdrag 4.}

Elev 1: Dobbeltsjekker for min del i hvert fall, som regel syns jeg det er lettere å gå på Google, også søke opp det jeg trenger, enn å drive å leite i læreboka, søker du på Google, så får du opp noe veldig enkelt.

Elev 2: Men som regel så er det sånn at i boka så står ting veldig sånn vagt, du får ikke noe ordentlig informasjon annen enn liksom: okey det skjedde- det skjedde noe sånt- også er det greit, men hvis du skulle vite hva som faktisk skjedde ikke sant så må du innom tre andre nettsider uansett og du får all den informasjonen som står i boka på de tre andre nettsidene allikevel og da er det ikke noe poeng i å sitte to timer å lese boka. Tenker jeg da.

Dobbeltsjekking og kryssjekking går igjen i disse elevenes praksiser. Her møter vi kildekomplementaritet, framstillingsform, sortering og dobbeltsjekking i en enkeltelevs praksis. Lærebokas faktaorientering og autoritative karakter 
balanseres her mot andre kilder for å verifisere opplysningene. Vi ser fremveksten av en kompetanse som er i slekt med vitenskapelige undersøkelser og såkalt "inquiry-based learning”. Samtidig ser vi at bruken av nettbaserte ressurser kontrasteres mot lærebok. Elev 2 gjør langt på vei læreboka irrelevant i sin omgang med læringsressurser.

Elevene i vårt materiale uttrykte et bevisst forhold til ulike kilder, og hvordan tilgangen på informasjon via Internett åpner opp for en praksis som er ny i forhold til lærebokas monopol på informasjonsmarkedet. Dobbeltsjekking av informasjon var også et tema som gikk igjen når elevene snakket om sin bruk av Wikipedia: “Jeg kan godt bruke Wikipedia, men da leser jeg fort gjennom hele og så går jeg over på en annen, da, og så ser jeg det som matcher, ikke sant, og da er det jo mest sannsynlig at det er korrekt”. Dette er i tråd med den vekt på kildekritikk og kildebruk som læreplanen vektlegger, og som også er rapportert spor av i undersøkelser av hvordan eksamen med tilgang til Internett fungerer (Rambøll, 2014). Det kan også virke som om denne praksisen smitter over også på analoge kilder:

\section{Utdrag 5.}

Intervjuer: $\quad$ Så du bruker læreboka som en sånn

Elev 3: $\quad$ Kildehenvisning- holdt jeg på å si- he he. Jeg sjekker opp mot det da. Men så fant jeg jo sist gang noe som ikke stemte med læreboka og det sto i en annen lærebok [på nett].

Intervjuer: $\quad$ I en annen lærebok ja?

Elev 3: $\quad$ I Historie. Ja så det var litt rart. Så det er litt forskjellige synspunkter.

Elev 4: $\quad$ Det er det jeg tenker og. At det er tryggest hvis du bruker læreboka fordi det er det som er pensum og det som er rett når du går på skolen. Selv om - du kan slå opp på Internett og du kan få noe helt annet som egentlig er rett, men det hjelper jo ikke om du lærer deg det fordi det er det som står i boka som læreren tar som rett. Så det er tryggere da og bruke boka. Fordi det er jo mange forskjellige synspunkter i historie.

Elevene reflekterer her over at det er ulike syn som presenteres i ulike kilder i historiefaget. Selv om elevene har en viss forståelse av hvilke kilder de kan regne som gode, og hvilke som er mer usikre, er dette en annen type kunnskap enn det å kunne vurdere kilder ut fra klare kriterier. Dermed blir igjen læreboka aktuell som en slags autoritet i fagfeltet. Som elev 4 uttrykker det: "det er tryggest hvis du bruker lereboka fordi det er det som er pensum og det som er 
rett når du går på skolen”. Disse elevene formidler at de er klar over både at historikere har ulike syn på historien og at dette reflekteres i kildene de møter. De uttrykker også et bevisst forhold til at skolen som institusjon har egne regler og normer som også innebefatter kunnskapssyn. I elevenes fortellinger om de nye hybride praksisene ble altså læreboka gjennomgående plassert som en stemme blant flere.

Men med tilgang til et mangfold av kilder inntrer også flere nye problemstillinger for elevene. Den første har vi allerede illustrert i form av troverdighet, sammenstilling, komplementaritet og vekting. Den andre dreier seg om å velge ut det som er relevant for oppgaven.

Internettkilder ble også gjennomgående ansett som “lettere” å forholde seg til, mens læreboka var mer krevende, iallfall rent språklig. I dette kan det ligge at læreboka har et mer konseptuelt eller vitenskapelig språk. Boka har relevant kunnskap samlet mellom to permer, men også her møter elevene utfordringer knyttet til utvalg og relevans. Alternativet er da å skape mening av fragmenter og tilmed motstridende opplysninger fra Internettet. Mens elever i lang tid har vært trent i å analysere informasjon og tekster, melder det seg nå et behov for å skape mening og synteser av ulike tekster og høyst variable resultater fra søk på nettet, noe studier har vist at elever ofte strever med (Mork Rogne \& Strømsø, 2013). I våre intervjudata viste imidlertid elevene at de hadde et bevisst forhold til at det å navigere og lage synteser av ulike informasjonskilder er både en krevende, men også en viktig kompetanse. Denne tendensen er tydeligst hos elevene på videregående trinn.

I intervjuene med elever i engelsk på videregående var bruken av nettbaserte ressurser i samarbeid et gjennomgående tema. Følgende beskrivelse er gjenkjennelig: "Det er jo med hjelp av teknologi vi fikset og samarbeidet for det meste. Eller fordi vi får stoff fra Internett og sånn". Elevene forteller om bruk av Facebook eller andre nettbaserte verktøy som e-post eller chat for å spørre om lekser, om sirkulering av PowerPoints kvelden før framføringer og om innehold. Samarbeid handler ofte om arbeidsfordeling og informasjonsinnhenting: "først så søkte vi eller fant informasjon. Hva er egentlig relevant og hva kan vi ta bort fra det tankekartet og den disposisjonen vi hadde. Så vi satt igjen med det vi syntes var viktigst og så fordelte vi det”. Denne beskrivelsen av samarbeidsprosessen viser at elevene har erfaring med å samarbeide og de kan sette ord på hvordan de organiserer arbeidet. Vi har ikke i intervjuene spurt spesifikt om oppgavetypene, men ut fra elevenes beskrivelser kan vi gå ut fra at oppgavene de jobber med er relativt sett omfattende og åpne - sett fra elevenes perspektiv. I det følgende utdraget reflekterer en gruppe elever på ungdomstrinnet over en gruppeoppgave i engelsk. 


\section{Utdrag 6.}

Elev 3: Det er liksom, hvordan de påvirker oss, det har jo mye med vår fremtid å gjøre og hvordan vi har det nå. Og vi kan også en del om det fra før, det er liksom - hverdagslige ting som vi har sett på TV.

Elev 4: $\quad$ Det er ting som angår oss ganske mye med tanke på, når vi snakker om TV og musikk og litteratur da, for så vidt, og politikk da for så vidt

\section{Elev 5: Politikk}

I utdragene ovenfor ser vi tydelig hvordan oppgavens relevans for elevenes livsverden er avgjørende for motivasjonen for å ta fatt på den. Dette kan være en av årsakene til at Internett oppleves som en viktig ressurs all den stund nettet tilbyr informasjon for nær sagt alle interesser og idiosynkrasier.

Nye ressurser kommer alltid med en pris, de trer ikke sømløst inn i eksisterende praksiser, de kan virke utfordrende og forstyrrende. Distraksjon trer i vårt materiale fram som et tema både lærere og elever er opptatt av, men de har et noe ulikt syn på årsaken til at de lar seg distrahere. Som nevnt tidligere så er distraksjoner ikke en iboende egenskap ved Internett, men er koblet til forholdet mellom tilgjengelige ressurser og hvordan de settes i spill i konkrete situasjoner. «Når det er dødtid da sporer jeg av, når det ikke er noe å gjøre også er det- ja, da går jeg inn på Facebook eller et eller annet sånt» Dødtid handler om å vente og om å kjede seg. Skoledagene er lange og skoleåret er langt. I det følgende utsagnet ser vi hvordan et skoleår kan fortone seg fra en elevs perspektiv:

\section{Utdrag 7.}

Elev 6: På begynnelsen av skoleåret var jeg også ganske flink til å ikke sitte på Facebook og sånne ting, men jo mindre- eller, det er jo kjedeligere og kjedeligere for meg, for hver uke og da mister du motivasjonen og da orker du ikke. Når du kommer på skolen og har stått opp tidlig og er trøtt, så gidder du ikke å følge med, rett og slett, da sitter du bare på Facebook eller noe- leser avisa. Læreren prater jo i et kjør ikke sant, så da på en måte, hvis du detter litt ut, hvis du på en måte mister konsentrasjonen din i to minutter

Eleven kobler ikke-produktiv bruk av digitale ressurser til fagformidling som oppleves som "kjedelig” eller som “dødtid”. Selv om teknologiene i seg selv kan ha forføreriske dimensjoner, er det ifølge denne informanten selve undervisningsdesignet som ikke holder partnerskapet mellom aktør og læringsressurs intakt. Dette har didaktiske implikasjoner, noe vi vender tilbake til den følgende sluttdiskusjonen. 


\section{Diskusjon: et partnerskap i endring?}

I den påfølgende diskusjonen knytter vi temaene fra analysen av intervjuene mot funn fra tidligere studier og den teoretiske rammen vi trakk opp innledningsvis, og vi bruker kontinuumet fra lukkede til åpne ressurser som et begrepsmessig bakteppe for å speile det empiriske materialet. Digitale ressurser representerer i stor grad det “åpne” universet hvor omløpshastigheten og tilfanget av potensielle ressurser er økende, fra oversettelsestjenester, "autentiske” tekster og virtuelle miljøer, til skreddersydde aktivitets- og oppgavesider. I spennet mellom åpne og lukkede ressurser forteller våre informanter om sine undervisningspraksiser. Noen lærere uttrykker at de står overfor nye utfordringer som de møter ved å utvikle nye praksiser, mens andre velger å holde på tradisjonene. Dette er også kjent fra andre studier av norske lærere (Aagaard, 2015). Ved å bruke lærernes og elevenes egne utsagn har vi forsøkt å beskrive hva som karakteriserer hybride praksiser. I det følgende løfter vi fram tre karakteristikker som fremkommer i vårt intervjumateriale.

Hybride praksiser karakteriseres for det første ved en sammenkobling av flere ulike ressurser og modaliteter - både analoge og digitale. Forlagene har også en tilsvarende blanding, da en rekke av læreverkene har tilleggsoppgaver og opplegg på relaterte nettsider. Vi ser altså at det sjelden er snakk om enten eller når det gjelder valg og bruk av læringsressurser. Denne hybriditeten preger i dag norske klasserom. ${ }^{2}$ Relasjonene mellom de ulike læringsressursene åpner dermed for design av både læringsomgivelser og forløp (Hauge, Lund, \& Vestøl, 2007). Særlig er det verdt å merke seg hvordan samarbeidsteknologier utgjør en match med svært åpne oppgavetyper, noe våre studier fra forskningsprosjektet TWEAK også tydelig viste (Lund \& Rasmussen, 2008). En viktig konklusjon var at tilgang på et rikere utvalg åpne læringsressurser må ses i sammenheng med de oppgaver som gis og de læringsmål som skal forfølges. I intervjuene begrunnet lærerne ofte utformingen av læringsomgivelsene i forhold til nye kompetanser som kreves.

For det andre viser intervjuene at læreboka ikke lenger framstår som "de facto curriculum”. Læreboka representerer et strukturerende element og har en viss "kanonisk" funksjon i forhold til hva som oppfattes som gyldig kunnskap av elevene. I møte med det “åpne” miljøet på Internett - som hele tiden er i endring - og hvor hver enkelt elev utformer egne søk og møter ulikt innhold, er dette en viktig rolle. Arbeidet med digitale ressurser for læring ser altså ut til å ha særegne utfordringer. En av disse er at elevene ikke har forkunnskaper nok til å bruke søk på Internett hensiktsmessig i sitt arbeid med oppgavene. I spenningsfeltet mellom åpne og lukka, digitale og analoge ressurser skal elevene utvikle grunnleggende ferdigheter i fag. Det er nettopp i dette spenningsfeltet vi ser behov for tilstedeværende lærere som utøver både faglig og profesjonsfaglig digital kompetanse (Lund et al., 2014). Slik sett blir læreren selv "limet” når det 
gjelder f. eks. kildevurdering og fragmentert og kanskje usikker nettbasert informasjon.

For lærerne har læreboka status som et utgangspunkt for videre utvikling av oppgaver og aktiviteter. Læreboka ser altså ut til å inngå i et mer helhetlig undervisningsdesign som læreren utformer hvor kopier, andre bøker og ressurser fra Internett anvendes. Når læringsressursene ikke er gitt, men "in the making”, så betyr det at lærerne raskt må kunne respondere faglig-pedagogisk på ting som dukker opp. Andre utfordringer knytter seg til at elevene forsvinner inn i parallelle Internettunivers. Vårt materiale viser at elever og lærere responderer ulikt på disse nye utfordringene. Selv om teknologiene kan være forførende så er det verd å merke seg at elevene oppgir vansker med å "henge med $i$ undervisningen" som hovedgrunn til "gå på nettet”. Lærerne skiller seg ved at enkelte tematiserer de didaktiske implikasjonene av dette gjennom å beskrive mulighetene for å variere og endre undervisningen, mens andre blir mer opptatt av det ekstra arbeidet kontroll av elevenes PC bruk medfører.

For det tredje ser vi at lærerne i økende grad designer egne undervisningsopplegg. Lærere bruker ikke ferdiglagde opplegg, de tilpasser og justerer for sine elever, der enkeltark med instruksjoner, veiledning eller arbeidsoppgaver kopieres og deles ut. Mens læreboka er en ferdigskrevet tekst utformet av andre, så suppleres den av de kopierte arkene utformet av lærerne. Arkene viser slik sett lærernes ideer og planer for undervisningen, og de formidler deres oppfatning av kompetansemålene før de blir iverksatt i undervisningen. Arkene er med på å synliggjøre og vektlegge lærernes prioriteringer. Her kommer deres undervisingsdesign, planlegging og intensjoner til uttrykk i møte med behov som oppstår i her-og-nå-situasjoner. I møtet med en mer kompleks læremiddelsituasjon uttrykker også enkelte lærerne at de får nye muligheter for variasjon og differensiering. Her ser vi hvordan det nye brukes og tilpasses idealer som har lange historiske røtter i den norske enhetsskolen, hvor et sentralt prinsipp har vært at elever med ulike forutsetninger går i samme klasse, og hvor undervisningspraksisen ideelt sett skulle fungere inkluderende.

Det betyr at læreren i økende grad kan betegnes som "designer" av læringsforløp og læringsomgivelser (Hauge et al., 2007). Gjennom design og bruk av læringsressurser tilfører også lærerne en form for materialitet i en profesjon som i høy grad har vært bygget på muntlige overleveringer og lav systematikk i utvikling av en synlig og lett tilgjengelig kunnskapsbase (Fenwick, 2012; Nerland, 2012). Dette er imidlertid praksiser som foreløpig er lite beskrevet i forskningslitteraturen, og dermed under-teoretisert. Videre forskning på hvordan læringsressurser velges, settes i spill, og plukkes opp av elevene kan være med på gjøre en viktig del av en slik kunnskapsbase synlig.

Studien vår viser at stadig flere informasjonsressurser og en heterogen elevpopulasjon øker kompleksiteten i profesjonsutøvelsen. Dette er en situasjon som aktualiserer lærerens kompetanse i å tilrettelegge elevenes læringsomgivelser og det krever det vi kaller designkompetanse hos lærerne. Det stilles 
altså utfordrende krav til en av aktørene i partnerskapet mellom lærer og læringsressurser. Høyere kompleksitet i læringsomgivelser og tilgjengelige ressurser ser altså ut til å medføre at betydningen av yrkesprofesjonaliteten læreren utviser øker. Dette kan imidlertid ikke bare være et individuelt ansvar, men et institusjonelt (lærerutdanning, skoler) og utdanningspolitisk anliggende.

\section{Referanser}

Aagaard, T. (2015). Når teknologi møter fagtradisjoner i norsk og mediefag på videregående skole. Acta Didactica Norge, 9(1), 1-20.

Alexander, R. (2000). Culture and Pedagogy - International Comparisons in Primary Education. Oxford: Blackwell Publishing.

Anmarkrud, Ø., Bråten, I., \& Strømsø, H. I. (2014). Strategisk kildevurdering av multiple tekster: Utbytterikt, men krevende. Norsk Pedagogisk Tidsskrift, 98(1), 47-57.

Bachmann, K. E. (2005). Lereplanens differens: formidling av læreplanen til skolepraksis. Trondheim: NTNU.

Blikstad-Balas, M. (2012). Digital Literacy in Upper Secondary School - What Do Students Use Their Laptops for During Teacher Instruction? Nordic Journal of Digital Literacy, 2(7), 81-97.

Blikstad-Balas, M. (2014). Lærebokas hegemoni - et avsluttet kapittel? In R. Hvistendahl \& A. Roe (Eds.), Alle tiders norskdidaktiker. Festskrift til Frøydis Hertzberg på 70årsdagen den 18. november 2014 (pp. 325-348). Oslo: Novus forlag

Bonnet, G. (2004). The assessment of pupils' skills in English in eight European countries 2002. Paris: The European Network of Policy Makers for the Evaluation of Education Systems.

Braun, V., \& Clarke, V. (2006). Using thematic analysis in psychology. Qualitative Research in Psychology, 3(2), 77-101.

Brevik, L. M. (2014). Making implicit practice explicit: How do upper secondary teachers describe their reading comprehension strategies instruction? International Journal of Educational Research (ijer)(67), 52-66.

Brutt-Griffler, J. (2004). World English: A Study of its Development. Clevedon, Buffalo, Toronto: Multilingual Matters Ltd.

Council, A. T. (1994). History Textbooks: A Standard and Guide. Retrieved from

Crystal, D. (2001). Language and the Internet. Cambridge: Cambridge University Press.

Denzin, N. K., \& Lincoln, Y. S. (1998). The Art of Interpretation, Evaluation , and Presentation. In N. K. Denzin \& Y. S. Lincoln (Eds.), Collecting and Interpreting Qualitative materials (pp. 275-281). London: SAGE.

Fenwick, T. (2012). Understanding transitions in professional practice and learning. Towards new questions for research. Journal of Workplace Learning, 25(6), 352-367.

Furberg, A. L., \& Rasmussen, I. (2012). Faktaorientering og forståelsesorientering i elevers bruk av nettbaserte læringsomgivelser. In T. E. Hauge \& A. Lund (Eds.), Små skritt eller store sprang? Om digitale tilstander i skolen (pp. 23-57).

Gimenez, T., \& Sheehan, S. E. (2008). Global citizenship in the English language classroom. UK:: British Council.

Haug, P. (2011). Klasseromsforskning - Kunnskapsstatus og konsekvensar for lerarrolla og lerarutdanninga. Rapport 21.

Hauge, T. E., Lund, A., \& Vestøl, J. M. (2007). Undervisning i endring: IKT, aktivitet, design [Teaching in transformation: ICT, activity, design]. Oslo: Abstrakt forlag. 
Hellekjær, G. O. (2009). Academic English reading proficiency at the university level: A Norwegian case study. Reading in a Foreign Language, 21(2), 198-222.

Hellekjær, G. O. (2012). Fra Reform 94 til Kunnskapsløftet: en sammenligning av leseferdigheter i engelsk blant avgangselever i den videregående skolen. In N. Hopfenbeck, M. Kjærnsli, \& R. V. Olsen (Eds.), Kvalitet i norsk skole: Internasjonale og nasjonale undersøkelser av læringsutbytte og undervisning (pp. 153-171). Oslo: Universitetsforlaget.

Horowitz, R., \& Olson, D. R. (2007). Texts That Talk: The Special and Peculiar Nature of Classroom Discource and the Crediting of Sources. In R. Horowitz (Ed.), Talking Texts. How Speech and Writing Interact in School Learning (pp. 55-90). Mahwah, New Jersey: LEA.

Jensen, K. (2008). ProLearn: Profesjonslæring i endring. Retrieved from Oslo:

Justvik, N. M. (2014). Lærebokas dominerende posisjon i historieundervisningen - bare for elevenes skyld? Acta Didactica Norge, 8(1).

Juuhl, G. K., Hontvedt, M., \& Skjelbred, D. (2010). Lœremiddelforsking etter LK06. Eit kunnskapsoversyn. Høgskolen i Vestfold: Høgskolen i Vestfold.

King, N. (1998). 'Template Analysis'. In G. Symon \& C. M. Cassell (Eds.), Qualitative Methods in Organizational Research: A Practical Guide (pp. 118-134). London: Sage

Klette, K., Lie, S., Ødegaard, M., Anmarkrud, Ø., Arnesen, N. E., Bergem, O. K., \& Roe, A. (2008). Rapport om forskningsprosjektet PISA+. Oslo: Norges forskningsråd.

Kvale, S. (2010). Det kvalitative forskningsintervju (2.utgave ed.). Thousand Oaks: SAGE Publications, Inc.

Lund, A. (2004). The Teacher as Interface. Teachers of EFL in ICT-Rich Environments: Beliefs, Practices, Appropriation. (PhD), University of Oslo.

Lund, A., Furberg, A., Bakken, J., \& Engelien, K. (2014). What Does Professional Digital Competence Mean in Teacher Education? Nordic Journal of Digital Literacy(4/2014).

Lund, A., \& Rasmussen, I. (2008). The right tool for the wrong task? Match and mismatch between first and second stimulus in double stimulation. International Journal of Computer-Supported Collaborative Learning (ijCSCL), 3(4), 25-51.

Lund, E. (2009). Å være digital i historie. In H. Otnes (Ed.), Å være digital i alle fag (pp. 3147). Oslo: Universitetsforl.

Lund, E. (2011). Historiedidaktikk. En håndbok for studenter og læerere. Oslo: Universitetsforlaget.

Mork Rogne, W., \& Strømsø, H. I. (2013). Lesing av delvis motstridende tekster i syvende klasse. Acta Didactica Norge, 7(1), 1-17.

Nerland, M. (2012). Professions as knowledge cultures. In D. Livingstone \& D. Guile (Eds.), The Knowledge Economy and Lifelong Learning: A Critical Reader. Rotterdam: SENSE Publishers.

Rambøll. (2014). Evaluering av eksamen med tilgang til Internett på eksamen 2014-2015. Retrieved from Oslo:

Rasmussen, I., Gilje, Ø., Ferguson, L. E., Ingulfsen, L., \& Bakkene, H. (2014). Kildearbeid, ideologier og oppgaveforståelse i historie. En casestudie i prosjektet ARK\&APP, samfunnsfag, videregående (ISBN: 978-82-569-7011-7). Retrieved from Oslo:

Rasmussen, I., Rindal, U. E., \& Lund, A. (2014). Leringsressurser og arbiedsformer $i$ engelsk: ungdomsskoleelevers arbied med sjangeren fantasy. En casestudie i prosjektet ARK\&APP, engelsk 8. klasse (1). Retrieved from Oslo:

Shaffer, D. W., \& Clinton, K. A. (2006). Toolforthoughts: Reexamining Thinking in the Digital Age. Mind, Culture, and Activity, 13(4), 283-300.

Skjelbred, D. (2010). Fra fadervår til Facebook - Skolens lese- og skriveopplering i et historisk perspektiv. Oslo: Fagbokforlaget. 
Skjelbred, D., \& Åmotsbakken, B. R. (2008). Norsk Lærebokhistorie - en kultur og dannelseshistorie: Novus forlag.

Säljö, R. (2010). Digital tools and challenges to institutional traditions of learning: technologies, social memory and the performative nature of learning. Journal of Computer Assisted Learning, 26, 53-64.

Vygotsky, L. S. (1986). Thought and Language (A. Kozulin, Trans.). Cambridge, MA: MIT Press.

Wertsch, J. V. (1998). Mind as Action. New York: Oxford University Press.

Wineburg, S. S. (2001). Historical Thinking and Other Unnatural Acts: Charting the Future of Teaching the Past (Critical Perspectives On The Past) Philadelphia: Temple University Press.

\footnotetext{
${ }^{1}$ I metodedelen beskrives bruken av data fra forskningsprosjektene. TWEAK: Tweaking Wikis for Education and Advancement of Knowledge (2008-2012) har studert wikier og andre læringsressurser i fagene engelsk og historie. ARK\&APP prosjektet (2013-2015) undersøker læremidler i planleggingen, gjennomføringen og vurdering av undervisning.

${ }^{2}$ Se Ark\& App rapportene: http://www.uv.uio.no/iped/forskning/prosjekter/ark-app/
} 